\title{
Review of Brand lmage Study
}

\author{
Shu Zhang \\ Wuhan University of Science and Technology \\ Wuhan, China 430000
}

\author{
Qinglin Luo \\ Wuhan University of Science and Technology \\ Wuhan, China 430000
}

\begin{abstract}
Through understanding the definitions of brand image in China and other countries, this paper summarizes the theory and model of it. From the perspective of the brand composing dimensions, views on brand image composing dimensions in and out of China are analyzed, and the "big five" model of brand personality dimension is thus obtained. At present, there are some differences in brand image theories in China and abroad, but the future brand image theories will show diversified development under the market leadership, which is also a good opportunity for cross-disciplinary research on brand image.
\end{abstract}

Keywords-brand image; brand image theory; composing dimensions; "big five" model

\section{INTRODUCTION}

What is brand image? Kenneth Boulding, in his book "the Image: Knowledge in Life and Society", argues that a symbolic image is "an intricate generalization or symbol of rules and structures". At present, many scholars both in China and abroad have defined brand image, which can be roughly divided into the following categories.

- Psychological elements

Sidney Levy proposed that brand image is the comprehensive reaction of brand elements in people's psychology.

\section{- Brand strategy factors}

Ronozzi and Gunterman believe that brand image is an associative set of the meaning of product or service differentiation in competition.

- Influencing factors

Biel believes that brand image is composed of the attributes that consumers associate with brand names. Aaker defines brand image as a combination of consumers' association with brands.

- Focus on personality factors

Sze put forward that brand image should have personality image like people, equating brand image with personality image. Plummer points out brands can be described by human personality, and brand personality is an important dimension of brand image.

- Other aspects
Killer believes that brand image is one of the associations related to brand in consumers' memory. Parker et al. put forward that "brand image comes from the concept of brand management of marketers, and brand image is a method of brand management". In 1991, Aaker linked the brand image with the assets and liabilities of the brand. He believed that the name could be added or deducted according to the symbols. Domestic scholars such as Luo Ziming and Fan Xiucheng reflect the connotation of brand image from the perspective of empirical research, which makes the measurement of brand in China more operable.

\section{FOREIGN THEORIES AND MODELS OF BRAND IMAGE}

\section{A. David Ogilvy's "Brand Image" Theory}

David Ogilvy put forward the Brand Image Theory in the 1950s, pointing out that "Brand is an intricate symbol, which is the intangible sum of Brand attributes, name, packaging, price, history, and reputation and advertising methods. His basic ideas are as follows.

1) Making a difference: It is necessary to create the unique characteristics of the brand to avoid homogenization. Establishing a prominent image for the brand can gain a larger share and profit for the manufacturer in the market.

2) Building personality: Ogilvy believes that image refers to personality. It is the brand's overall personality that ultimately determines the brand's market position and brand personality can make brand image unique.

3) Reflecting the image of consumers: Brand image reflects the buyer's self-image, thus the low-end brand image will not attract consumers.

4) Long-term contribution: Ogilvy believes that every advertisement should be a long-term investment in the brand, and the advertisement must maintain a consistent image and style.

5) Comprehensive factors: There are many factors that affect the brand image, such as its name, packaging, price, advertising style, sponsorship and time spell on the market.

6) Long-term goals: Brand image is a long-term strategy and investment, and setting long-term goals can make the image grow and enrich.

\section{B. Brand Identity System Model of David Aaker}

Brand identity and brand image are actually two sides of one thing. Brand image is the overall perception of brand identity, and brand identity is the benchmark to guide the 
construction of brand image. Therefore, the construction of brand identification system proposed by the famous American brand expert David Aaker is of great reference value to people's understanding of brand image. According to the system, brand recognition is considered from the four perspectives of product, organization, individual and symbol. Relevant associations of product identification include product scope, product attribute, product quality/value, association about users and connection with countries or regions, etc. The brand perspective of an organization focuses on organizational attributes rather than product or service attributes. Organizational attributes such as innovation, quality drive and concern for the environment are established by the company's employees, culture, values and activities. Brand recognition from the perspective of individual brand is richer and more interesting than brand recognition based on product attributes. Just like the characteristics of a person, a brand can also be considered to have such as high-level, trustworthy, young and smart and other characteristics. The perspective of brand as a symbol means that strong symbols can help brand recognition gain cohesion and establish structure, and make the identification and representation of brand easier.

\section{The Brand Image Model of Bell}

Alexander Bell, an American scholar, believes that brand image can be reflected through the three sub-images of corporate image, user image and product/service image, and the starting point of brand image description is consumers' association with brand related characteristics. The attributes of these associations can "hard" or "soft". The so-called "hard" attributes refer to the cognition of the tangible or functional attributes of a brand. As for cars, the relevant hard features are powerful horsepower and fast start. Once a brand gains an "exclusive position" to a certain functional attribute, it is often difficult for other brands to position themselves based on this attribute. But the hard attribute is no longer the absolute factor forming the brand difference. While the "soft" attribute reflects the emotional interests of the brand. The "mustang", for example, is easily associated with masculinity, freedom and adventure. Consumers organize all kinds of information about enterprises and experience of using enterprise products into enterprise image, which can also be called organizational image. Its constituent elements mainly include innovation, historical continuity and social marketing awareness, as well as a sense of trust to consumers. User image refers to the demographic characteristics of brand users, which are the "hard" characteristics, yet also including the soft characteristics such as the user's personality, values and lifestyle. The product or service image is the brand characteristic corresponding to the benefit characteristics brought by the product or service itself. The product origin, packaging and the needs it can meet all constitute the image of the product or service. The contribution of the three different sub-images to brand image will vary according to different products (brands). In China, the corporate image of brand is very important, and often those strong, good reputations of corporate image will make consumers feel more reliable of the products.

\section{Brand Image Theories in China}

1) Luo Ziming's theory of brand image measurement: Luo Ziming believes that brand image is the comprehensive reflection of brand elements in people's psychology and people's subjective evaluation of the brand. According to him, the brand image is composed of five aspects: brand cognition, product attribute cognition, brand association, brand value and brand loyalty. Brand cognition mainly refers to the cognitive state of brand name, brand identity, enterprise name and other aspects. Brand awareness has a great impact on the cognitive state, which is also the first step of brand image cognition. Product attribute cognition is the basis of brand image value theory, and product attribute is the basis for consumers to obtain the value of goods, which also emphasizes that enterprises must first strengthen the product's function, attribute, quality and other aspects when building the external brand image of products. Psychologists include some related information association activities in people's daily life as an important factor affecting consumers' purchasing behaviors. Therefore, brand association comes into the research scope of brand image and corresponding indicators are subdivided. After the purchase behavior, consumers will judge whether the products they buy are of value to themselves, which is their evaluation of the brand value. Brand image has strong subjective color. The ultimate purpose of building brand image is to promote consumers' purchasing behavior, which is often reflected in people's loyalty to the brand.

2) Fan Xiucheng's theory of brand image evaluation: Fan Xiucheng, a Chinese scholar, thinks that enterprises should build brand image first by constructing brand identification system. From the perspective of consumers, brand image reflects customers' perception of the brand. As for the difference of brand image and brand recognition, the former is from the perspective of receiver, which is the way for the public to interpret the brand through all signals sent by products, services and communication activities, and is a receptive concept. The latter is from the perspective of communicator, whose task is to elaborate the meaning, goal and mission of the brand. Image is the result of this interpretation, the inference and interpretation of the meaning of the brand. It can be seen that brand recognition represents a state that an enterprise hopes to achieve, while brand image is reflected in the fact that consumers view the brand. In brand management, brand identity is formed before brand image. In this regard, Fan Xiucheng made a conceptual distinction between brand recognition and brand image (as shown in "Fig. 1"). He believes that only by actively creating brand image and guiding brand image on the basis of brand recognition and letting customers have expected brand association, can a real brand image be established. 


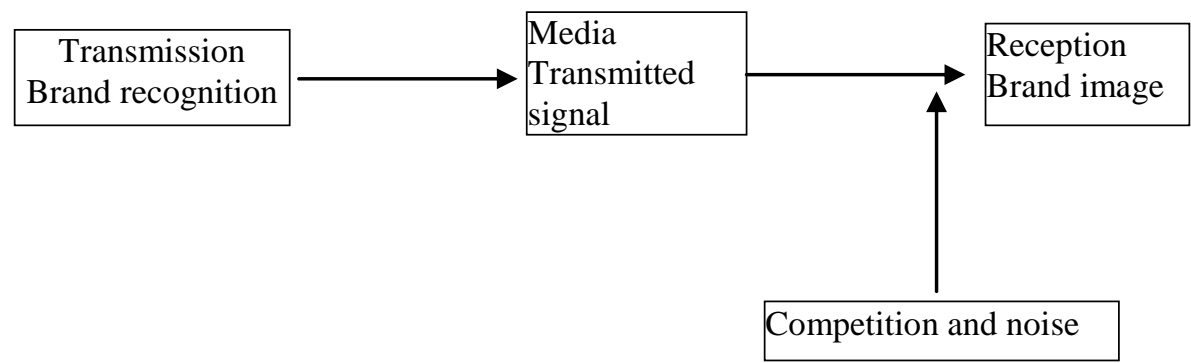

Fig. 1. Brand recognition and brand image.

According to the brand identification system proposed by David Aaker, the brand image composition can be divided into four dimensions: product dimension, enterprise dimension, humanization dimension and symbol dimension.

a) Product dimension: Product attributes bring the most basic and substantial functions and benefits to consumers, which is also the most basic requirements of consumers. Because the product is the physical carrier of the brand, some of the advantages of the product itself, such as function, use or origin, can often stimulate the purchase intention of consumers.

b) Enterprise dimension: It refers to that when consumers pay attention to a product, they also start to pay attention to the enterprise that produces and provides the product. The image of the enterprise is the powerful support behind the product. For example, the history, source country, strength and other factors of the enterprise will affect the degree of consumers' recognition of the product.

c) Humanity dimension: Personification of the brand will make consumers have a richer and more interesting understanding of the brand image. d) Symbol dimension: It refers to all kinds of graphics, symbols, texts or their combinations that constitute brand logos. This visual symbol is not only helpful for consumers to remember the brand, but also can inspire consumers to associate with the brand.

\section{BRAND IMAGE COMPOSING DIMENSIONS}

\section{A. Analysis of Brand Image Composing Dimension Theories}

In recent years, both Chinese and foreign scholars believe that brand image is composed of multiple dimensions, and the answer is not standardized and absolute. Wang Changzheng and Shou Zhigang argue in "Review of Western Brand Image and Its Management Theory", "the current disagreement is not that brand image is composed of social and psychological elements unrelated to products, or psychological elements unrelated to products, but is in the specific elements contained in different theoretical models."

TABLE I. ANALYSIS OF BRAND IMAGE COMPOSING DiMENSION THEORIES MADE By CHINESE AND FOREIGN SCHOLARS

\begin{tabular}{|c|c|c|c|}
\hline Scholar & Brand image composing dimensions & Advantages & Disadvantages \\
\hline Keller & Attributes, interests, attitudes & $\begin{array}{l}\text { systematisms, } \\
\text { comprehensiveness and } \\
\text { universality }\end{array}$ & $\begin{array}{l}\text { Complexity, difficulty of } \\
\text { being proved }\end{array}$ \\
\hline Biel & $\begin{array}{lccc}\begin{array}{l}\text { Corporate image, } \\
\text { product/service image }\end{array} & \text { user } & \text { image, } \\
\end{array}$ & $\begin{array}{l}\text { Intuitiveness, great } \\
\text { practical significance }\end{array}$ & $\begin{array}{l}\text { Simpleness, } \\
\text { incompleteness }\end{array}$ \\
\hline Belen & $\begin{array}{l}\text { Assurance, personal } \\
\begin{array}{l}\text { identification, } \\
\text { social identification, }\end{array} \\
\text { identification }\end{array}$ & $\begin{array}{lr}\begin{array}{l}\text { Perspective } \\
\text { great } \\
\text { significance }\end{array} & \text { practical } \\
\end{array}$ & $\begin{array}{l}\text { Relatively brief content, } \\
\text { limited coverage }\end{array}$ \\
\hline Aaker & $\begin{array}{l}\text { Products, organization, individual, } \\
\text { symbol }\end{array}$ & $\begin{array}{l}\text { Revealing the } \\
\text { relationship between } \\
\text { brand image and equity }\end{array}$ & $\begin{array}{l}\text { Unsystematic } \\
\text { confusing content }\end{array}$ \\
\hline Kapherer & $\begin{array}{l}\text { Physique, personality, culture, } \\
\text { relationship, reflection, self-image }\end{array}$ & $\begin{array}{l}\text { Strong integrality, } \\
\text { comprehensiveness }\end{array}$ & $\begin{array}{l}\text { Difficulty of being } \\
\text { proved }\end{array}$ \\
\hline Fan Xiucheng & $\begin{array}{l}\text { Products, enterprises, humanization, } \\
\text { symbols }\end{array}$ & $\begin{array}{l}\text { Intuitiveness, great } \\
\text { practical significance }\end{array}$ & Limited coverage \\
\hline Luo Ziming & $\begin{array}{l}\text { Brand cognition, product attribute } \\
\text { cognition, brand association, brand } \\
\text { value, brand loyalty }\end{array}$ & $\begin{array}{lr}\text { Comprehensive system } \\
\text { and } \\
\text { perspective }\end{array}$ & $\begin{array}{l}\text { Difficulty } \\
\text { proved }\end{array}$ \\
\hline
\end{tabular}

There are relatively recognized brand image in the academic world, such as the hexagonal prisms proposed by hexagonal prisms, the brand image model proposed by Keller, the three dimensional model proposed by Biel, as well as the ideas of Belen, Aaker, Fan Xiucheng and Luo Ziming.
Foreign scholars such as Kapferer, Keller, Biel, Belen and Aaker have systematic and comprehensive perspectives on the composition of brand image, thinking about the composition of dimensions from the perspective of brand image and brand recognition. On the basis of learning from and absorbing foreign theories combined with the actual 
situation of local brands, domestic scholars put forward the relevant views that are easy to understand and grasp systematically. The analysis and comparison table of brand image composition dimensions is sorted out through resourcing, (as shown in "Table I").

\section{B. The "Big Five" Model of Brand Personality}

In the "Brand Image Comprehensive Evaluation Model and Its Application", Fan Xiucheng and Chen Jie took Jennifer L. Aaker's big five model of brand personality as an argument in the humanization dimension. Therefore, it can be inferred that the big five model of brand personality dimension is built on the brand image system. The "big five model" of Brand personality dimension proposed by Jennifer L. Aaker is a definition accepted and respected by more scholars, and it studies brand personality and its dimensions through the use of induction. Aaker believes that brand personality can be directly expressed by consumers' personality, which is the result of projecting human personality characteristics onto the brand, and emphasizes the importance of emotion in the brand. On this basis, Jennifer L. Aaker developed a systematic brand personality dimension scale for the first time based on the "big five" model of western personality theory, taking the trait theory and vocabulary method as the methodology basis, starting from the personality psychology dimension, taking famous western brands as the research object and relying on modern statistical techniques. In this scale, brand personality is divided into five dimensions of "sincerity, stimulation, competence, delicacy and firmness", each of which has its own brand characteristics. (As is shown in "Table II")

TABLE II. JENNIFER L. AAKER's "BIG FIVE" MODEL OF BRAND PERSONALITY DIMENSION AND CHARACTERISTICS

\begin{tabular}{|c|l|}
\hline $\begin{array}{c}\text { Brand personality } \\
\text { dimensions }\end{array}$ & \multicolumn{1}{|c|}{ Characteristics } \\
\hline Sincerity & $\begin{array}{l}\text { Love for, honesty, sincerity and } \\
\text { happiness }\end{array}$ \\
\hline Stimulation & Courage, spirit, imagination, fashion \\
\hline Competence & $\begin{array}{l}\text { Trust, resonsibility, reliability, } \\
\text { effectivity }\end{array}$ \\
\hline Delicacy & Charm, flaunt, glamour, romance \\
\hline firmness & burliness, strengh, outdoors, firmness \\
\hline
\end{tabular}

The generation of this model is complex and scientific. Aaker mainly used three sources when looking for the selection of brand personality and image features, that is, 204 combinations of stable, reliable and trustworthy human personalities found according to psychological research, the personality scale used by academics and industry professionals including 113 unique characteristics, and the 295 factors obtained from sixteen consumers who were asked to take the brand association test. On this basis, Jennifer 1 . Aaker reduced the number of personality elements to the number of better operation after several tests and screening of large samples, and finally extracted the above five brand personality dimensions from the 114 elements.

Aaker's definition of brand personality and the research model developed from it are the most representative research results in this field at present, and have breakthrough significance for the research on the composition dimension of brand image.

\section{CONCLUSION}

Through sorting out and analyzing the brand image theory, this paper finds that the foreign brand image related theories are relatively specific and comprehensive. Based on the theoretical model, two-way researches are conducted combined with other disciplines and fields and applied to the brand image. At present, Chinese scholars' research on brand image is based on foreign research theories, and some relevant theories are put forward in combination with domestic brand market conditions. Although theories are constantly enriched and improved, efforts are still to be intensified in interdisciplinary research to find the intersection between the two disciplines and conduct indepth research and analysis. The future brand image theory will present the diversified development under the market leadership, which is also a good opportunity at the same time.

\section{REFERENCES}

[1] Duan Yunhui. Construction of brand image at the client-side of The Paper [D]. Shandong Normal University, 2018. (in Chinese)

[2] Zhang Junni. Empirical research on the correlation between brand personality and consumer personality [J]. Economic Science, 2005 (6) (in Chinese)

[3] Luo Ziming. Composition and measurement of brand image [J] Journal of Beijing Technology and Business University (Social Science), 2001 (4). (in Chinese)

[4] Zheng Shaohua. Research on the constituent dimension of brand image [J]. Industrial \& ScienceTribune, 2008(3). (in Chinese)

[5] Guan Hui. Practical Research on the Brand Image influence and Its Effects on Consumers Behavior Intension [J]. China Business and Market, 2007(7). (in Chinese)

[6] Liu Can. Overview of brand image and its constituent dimensions [J] Modern Marketing, 2018(8). (in Chinese)

[7] Fan Xiucheng. Measurement of Brand Image: A Brand IdentityBased Integrated Model and Empirical Study [J]. Nankai Journal (Philosophy, Literature and Social Science Edition), 2002(3). (in Chinese)

[8] Lin Cailin. Brand Image and Design [M]. Shanghai: Shangha Jiaotong University Press, 2012. (in Chinese) 